\title{
Collision Principles in Labor Relations Complicated by a Foreign Element: Experience of Uzbekistan
}

\author{
Musaev Bekzod Tursunbaevich
}

\begin{abstract}
: various scientific debates are taking place today not only at the national level but also within the framework of international organizations on the role of countries, international organizations on issues of legal regulation of foreign citizens' activities, foreign labor migration and its legal regulation. The main reason for this is sharp increase of labor migration process in the world in recent years, growing aspirations of foreign citizens in carrying out activities in other countries, as well as involvement of foreign professionals in working in other countries as the result of attracting foreign investment, signing bilateral agreements of employment on the basis of the principle of reciprocity between the two states. Bringing national legislation on human rights in accordance with international standards, development of foreign economic activity of enterprises and organizations entail the emergence and increase of labor relations with so-called foreign element. Based on this, in this article, different aspects of collision-legal regulation of labor relations with complicated foreign element are covered and analyzed. In this, the author pays attention to the types and importance of collision norms governing international labor relations, as well as the principle of autonomous will as a method of collision-legal regulation of labor relations.
\end{abstract}

Keywords : foreign element, collision norm, the principle of autonomous will, free choice of rights (lex volutatis); law at the place of work (lex loci laboris); flag act (lex flagi); law of the country of institution, business travelers' (lex loci delegationis) and others.

\section{INTRODUCTION}

In recent years, in not only the Central Asian countries, but also in Western European countries labor migration issue and its legal regulation has become one of the significant topics. This is estimated in the Global Estimate on Migrant Workers of ILO (International Labor Organization) in 2018. According to it, there are 258 million international migrants, 234 million migrants of working age (15 and older) 1 and 164 million migrant workers worldwide.

For the purposes of this report, the term "international migrants" refers to persons who are foreign-born (or foreign citizens when place-of-birth information is not available), while the term "migrants of working age (15 years of age and over)" is a subset of international migrants.

Overall, migrants of working age constitute 4.2 per cent of the global population aged 15 and older, while migrant workers constitute 4.7 per cent of all workers. In destination countries, the higher share of migrant workers among the global workforce than among the global population of working age is due to the higher labour force participation rate of migrants (70.0 per cent) compared to non-migrants (61.6 per cent) .

The importance of regulating labor relations, complicated by a foreign element is determined by the duty of a democratic state of law to provide and protect the rights of any person, including a foreign citizen or a stateless person conducting labor relations in the territory of that state. Legal problems of international labor are highly relevant. The internationalization of life and proclamation of a free movement of people, alignment of national legislation on human rights in accordance with international standards, development of foreign economic activity of enterprises and organizations entail the emergence and increase of labor relations with so-called foreign element.

By their nature, relations constituting the subject of international private law is a private law relationship (i.e. civil law relations in the broadest sense), complicated by a foreign element. These relationships are in addition to the actual civil law and labor relations arising in conditions of international life. Private law nature of labor relations is reflected in regulation of their use in well-known civilian categories agreement, law and legal capacity, indemnification, etc... The principles of private law regulation on labor relations determine the application of international private law categories and concepts to them. Inclusion of labor relations into the subject of international private law follows to the extent to which they have a civil law nature and thus go beyond one state.

Foreign element in the international labor relations can be present as in the subject composition (a foreign worker, foreign employer), and in the object (labor activity of an employee is performed abroad).

International private law norms regulate property, private morality, family, labor and procedural rights of foreigners Labor relationship with a foreign element, along with civil law relations are also included in the subject of international private law . Even the concept of a narrow interpretation of the subject of international private law, taking into account the complex form of nature of this branch of law allows including norms on labor relations of individuals in its subject . Two sources are clearly reviewed in their regulation: national legislation and international treaties. 
Two main features characterize relationships constituting the subject of international private law: firstly, it is international relations; secondly, it is civil law relations, and besides, the term "international" has a different meaning in comparison with this term in applying to international (public) law . In the latter, it is synonymous with the term "interstate", i.e. it has a narrow meaning. In applying to the international private law it is used in its broad sense: international - these are relationships that go beyond a single state that one way or another are related to the legal systems of different states.

\section{LITERATURE REVIEW}

Such international labor relations in nature are the subject of private international law - a private law relationship (i.e. civil relations in the broader sense), complicated by a foreign element. Private nature of labor relations reflects in itself the regulation of their use in the famous civil categories contract, legal capacity, reparations, etc. The principles of private regulation of labor relations, makes it necessary to apply categories and concepts of private international law with them. The inclusion of labor relations in the subject of private international law has significant civil nature and thus goes beyond one state .

Currently, among the experts on labor and international law, as the most common classification, international labor law (hereinafter - ICC) is considered as one of the branches of international law . In post-Soviet legal tradition, this position was first formulated by S.A.Ivanov . According to him, ICC was "a new branch of international law developed since the 2nd World War and designed to regulate relations between states in the improvement of working conditions". In some studies, this position is sometimes narrowed. For instance, A.O.Kharitonova would take ICC not only just as a branch of international law, but also as part of international human rights law, probably based on the previously expressed positions of specialists in the field of international law. Close to that wording, the ICC relates to international humanitarian law. In the earlier period ICC was a sub-branch of international law, under the name of "the law of the international cooperation on specific issues".

According to D.K.Bekyashev international labor law means not only the branch of international (public) law, but also the legal regulation of labor relations, complicated by a foreign element that experts on private international law are assigned to one of the institutions of the field .

There are other point of views among European experts. N.Valtikos in his monograph "international labor law" gives a concept defined as "a part of the labor law, which has international sources", pointing out that the employment relationship, complicated by a foreign element is the subject of private international law. J.M. Serve introduces international labor law as "a branch of law of international concern, and more particularly, the universal origin". We believe that this concept is not entirely clear; it whether means independent branch of law, or it comes to branches of international law. At the same time, the concept of international labor law is proposed to delete the regional legal regulation of labor and issues of conflict of application of national labor laws. In some studies the use of conflict of labor laws, on the contrary, is identified with the international labor law. L. Swepston writes that international labor law "applies to the material of the legal rules established at the international level, as well as the procedural rules relating to their adoption and implementation". A group of distinguished lawyers in the field of labor law from the United States by volume textbook on international labor law defines this concept as follows: "International labor law - a new field of study separate from a comparative labor law. It includes a "law" that crosses national boundaries - the legislation in quotation marks because it is not entirely certain body required for the application of legal norms supranational level". In this case, the textbook covers not only public sources, primarily ILO instruments, but also the activities of international non-governmental organizations, unilateral acts of States, corporate codes of conduct and national judicial decisions. D.V.Chernyaeva considers public international labor law as "a complex sub-sector employment and public international law", and I.V.Shesteryakova expressed the view that the ICC should be made "not in the sub-sector of the international but a separate branch of law". There is also a characteristic of the ICC as a "multi-complex legal framework"

We believe that the employment relations, complicated by a foreign element are the subject of private international law. This statement is confirmed in the statements of such prominent scholars as: H.R.Rahmankulov, M.M.Boguslavskiy, V.Y.Ergashev, S.Hamraev, I.S.Peretersky, L.A.Luntz, V.P.Zvekov, S.N.Lebedev, N.A.Haustova, G.K.Dmitrieva. These authors define the subject of private international law as a civil law relations (in the broad sense), complicated by a foreign element .

In particular, I.S.Peretersky said: "Private International Law studies civil law relations. But this does not mean that private international law is just one part of civil law. Specific differences in civil law relations, included in international private law, are the fact that the private international law studies only a special group of civil legal relations, which have an international character".

L.A.Luntz attributed to the sphere of private international law, not only civil, but also the family and labor relations. He wrote: "Private international law is a branch of law and jurisprudence which has civil nature in this broader sense, arising in international field" .

It should be noted that two main features characterize relationships that are the subject of private international law: firstly, it is international relations; secondly, it is civil relations, and the term "international" has a different meaning in comparison with the term as applied to international (public) law . In the latter, it is synonymous with the term "inter-state", i.e., it has a narrower meaning. Applied to the private international law, it is used in its broadest sense: international - these are relationships that go beyond a single state that one way or another related to the legal systems of different states.

Analyzing the question of the place of employment in the private international law is necessary to highlight the existing two points of view.

Proponents of the first view are the domestic and foreign scientists that set international labor law as an independent (separate) branch of law. 
In the 20s of the last century of the existence of international labor law, a German lawyer pointed Kutting G. and G. fon Toll, the French scientist Reynaud, Bulgarian scientists Yanulov I., M.Genovsky, as well as the West German lawyer F. Gamilmek. French lawyer Jacques Kamerlink and J. Lyon-Caen, analyzing international cooperation on improving working conditions, also noted the existence of international labor law .

Proponents of this position argue their opinion, pointing to significant differences between civil and labor laws, and the inapplicability of some of the classic rules of international private law to labor relations with a foreign element.

Representatives of the second viewpoint are scholars such as V.M. Chkhikvadze, TS.Ya. Yampolsky, E.M. Amethyst, V.P.Zvekov. They include private international labor law to the sub-sector of private international law. In support of its point of view, the scientists point out those labor relations should be solved with the help of approaches, principles and categories of private international law.

V.P.Zvekov believes that the system of regulations affecting labor relations with a foreign element forms a sub-sector of private international law - international private labor law, consisting of the substantive conflict of laws and regulations . Among the sources of private international labor law play a significant role statutes and staff regulations of international organizations, due to the peculiarities of transnational labor relations .

In the legal science rather established approaches, according to which one of the main distinguishing features of labor law as an industry is to combine it private and publicly-legal elements. Despite the presence in the labor law is very important for him to start the treaty, a sign of a fundamental labor right from the moment of its occurrence is considered to be a significant level of state interference in contractual relations employee and the employer to protect the economically weaker party.

We agree with this position and believe that the allocation of private international labor law as a sub-sector of private international law may be:

1) on the subject of regulation - a labor relations with a foreign element of a private nature. These relationships are united by common principles of private law regulation: legal equality and independence of parties to the employment contract, discretionary regulatory contractual nature of the occurrence and termination of the relationship, reparations, etc.

2 ) the method of legal regulation. Private international law and private international labor law are united by common methods of legal regulation, namely, the conflict of laws and substantive law.

\section{DISCUSSION AND ANALYSIS}

If we pay attention to the norms of the Labor Code of the Republic of Uzbekistan, it does not reflect the rights of independent definition of rights applied to the employment contract of the parties.

Let us consider the legal basis of the legal status of foreigners in the Republic of Uzbekistan, and their labor activities.

Article 23 of the Constitution of the Republic of Uzbekistan states: "Foreign citizens and stateless persons, during their stay on the territory of the Republic of Uzbekistan, shall be guaranteed the rights and freedoms in accordance with the norms of international law. They shall perform the duties established by the Constitution, laws, and international agreements signed by the Republic of Uzbekistan" . These norms apply to the labor relations of foreign citizens and stateless persons. This means that the legislation of the Republic of Uzbekistan is based on the application of national treatment principle in the field of labor relations.

It should be noted that labor relations of foreign citizens on the territory of the Republic of Uzbekistan is regulated by a number of normative-legal acts containing norms of direct action. The basis for this claim are the articles 10-12 of the Labor Code of the Republic of Uzbekistan, which provides for the application of national treatment in the sphere of labor relations with participation of foreign persons and stateless persons.

In particular, Article 11 of the Labor Code of the Republic of Uzbekistan states: "Legislation on labor applies to foreign citizens and stateless persons working on the territory of the Republic of Uzbekistan under a labor contract signed with an employer". This norm firmly approves the application of the conflict principle of lex loci laboris (law of the work place). The Rome Convention on law applicable to contractual obligations of 1980 is based on this same principle.

Therefore, the basic conditions of participation of foreign citizens in a labor relationship are regulated by substantive provisions of the Labor Code, according to which foreign citizens and stateless persons shall enjoy the right to freely dispose their abilities to work, choose the type of activity and profession, as well as the right to freely use their abilities.

According to the Labor Code of the Republic of Uzbekistan, an employer is an individual or legal person who has received permission to attract and hire foreign workers and employ foreign workers on the basis of signed employment contracts in the prescribed manner. A foreign citizen registered as an individual entrepreneur can act as an employer.

In the law of Uzbekistan, the norms regulating labor relationship are identified as an independent branch of law labor law, but labor relations belong to the same type of relationship as civil law (for example, the conclusion and termination of employment contract, the latter is considered as a variety of civil law contract). However, labor relations tend to as a civil law and administrative law regulation. In labor relations, there is share of administrative legal regulation, as well as the desire of a legislator to protect the interests of an employee (as a weaker party in an employment relationship) and to protect from possible abuse by the employer.

For replenishment of the gap of conflict regulation of labor relations, it is proposed to introduce chapter on "Application of norms of international private law to labor relations" into the Labor Code of the Republic of Uzbekistan. Initial position in this chapter must be based on the following: parties of labor relations decide themselves what the national system of labor law should be applied to the relationship. In other words, the parties themselves elect their national law for the contract.

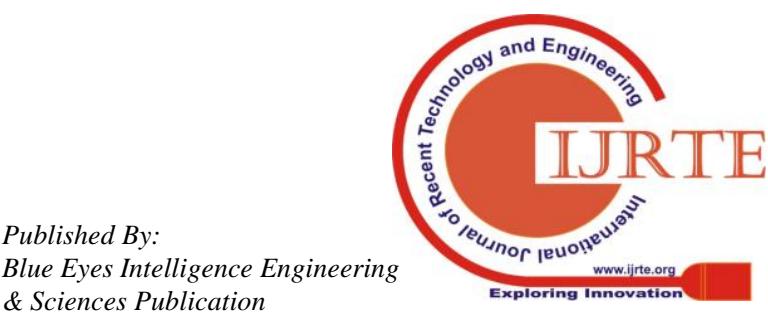


If the will of the parties of the employment contract is not identified, then the right will be applied to the employment contract - the right of the country in which the employee commonly carries out his work under the contract, even if he is temporarily performing his/her activities in another country, or if there is no country - law of the country, where the company that hired an employee, is situated. If circumstances show that, the contract is more closely connected with another country, it becomes a subject to the application of the law of that country.

In any case, we think that duration of a business trip and its objective should be the main criterion in determining conflict norms. At the same time, it should be noted that issues of labor relations of employees sent to business trips to foreign countries are not regulated with the norms of the current Labor Code of the Republic of Uzbekistan. An issue of the subject to the right of the state of relationship is also not defined by the legislation.

In our view, labor relations of employees of Uzbekistan should be regulated in accordance with labor legislation of the Republic of Uzbekistan. In this case, labor relations will be established not in the territory of a foreign state, but in the territory of the Republic of Uzbekistan, as well as an employee does not sign a contract on new labor relations with a company in a foreign country, but will continue labor relations with that company. However, while abroad, employees comply with the regime of working hours and rest periods established in enterprises and institutions, where they actually work, and they are obliged to follow the rules of internal regulations and instructions on safety in these enterprises.

\section{CONCLUSION}

Thus, analyzing the point of view of experts in the field of private international law, provisions of national legislation in different countries, we can draw the following conclusion:

Firstly, the employment relationship with a foreign element is the subject of private international law, as the relationships of a private nature (civil and labor relations are united by common principles of private law regulation: legal equality and autonomy of the parties, the dispositive regulation, contractual nature of origin, etc.). For the regulation of labor relations with a foreign element, there are two methods of private international law - collision and substantive.

Secondly, the literature suggested that the presence of certain categories of employment, need special regulation of conflict: the labor relations of employees of diplomatic missions and consular posts (these possible application of the law of the flag State); labor relations of employees of international organizations (used, for example, the right of the state where the headquarters of an international organization); labor relations of employees seconded abroad (possibly apply integrated management, in particular the law of the employer, or the right of the state of the traveling performance of the job $)^{2}$.We cannot fully agree with this idea. In our opinion, the term and aim of official journey should be main factor to define collisions in legislation.
In our opinion, labor relations regarding the employees from Uzbekistan should be regulated with national labor legislation. Because those labor relations do not evolve in the territory of foreign state, but Uzbekistan. In addition, the worker does not formalize documents with a foreign company located abroad, but continues labor relations with the company which sent him.

However, while abroad, workers are subject to the regime of work and rest periods, established in enterprises and institutions, which actually work. They are obliged to follow the rules and safety instructions in practice in these enterprises.

In the third, the autonomy of the will, which is one of the fundamental principles of private international law, labor law applies to a certain degree of caution (i.e., limited by the application of peremptory norms and super-imperative). In such situation, one side is the worker, and the legislator seeks to protect his interests.

Fourth, the allocation of private international labor law as a sub-sector of private international law, possibly as follows: 1) on the subject of regulation - a labor relations with a foreign element of a private nature. These relationships are united by common principles of private law regulation: legal equality and autonomy of the parties, the dispositive regulation, contractual nature of the origin and termination of the relationship, reparations, etc. 2) the method of legal regulation. Private international law and private international labor law are united by common methods of legal regulation, namely, the conflict of laws and substantive.

Fifth, analyzed the provisions of international treaties, national legislation and judicial practice, it can be concluded, according to which, the autonomy of the will, which is one of the fundamental principles of international private law and labor law applied with some degree of caution (i.e., limited by the application of the mandatory and super-imperative norms).

Sixth, the Labor Code does not provide for a choice of the right sides of the labor contract. At present the share of labor relations of administrative and legal regulation, as well as the desire of the legislator to protect the interests of the employee (as the weaker party in the employment relationship) and to protect against possible abuse by the employer. To bridge the gap of conflict regulation of labor relations proposed to the Labor Code of the Republic of Uzbekistan, we suggest entering a chapter under a name "Application of the rules of private international law to labor relations." Starting position in this chapter must be based on the following: the labor relations, the parties themselves decide what the national system of labor law should apply to the relations. In other words, the parties themselves elect their national law for the contract.

If the will of the parties to the employment contract is not found, then to the employment contract will be applied the law of the country in which the employee normally carries out his work under the contract, even if he is temporarily performing the job in another country, or if there is no country - law of the country, where the company hires an employee. If the circumstances show that the contract is more closely connected with another country, the application of the law of that country is acceptable. 


\section{REFERENCES}

1. https://www.ilo.org/wcmsp5/groups/public/---dgreports/---dcomm/--p ubl/documents/publication/wcms_652001.pdf

2. Boguslavskiy M.M. International private law: Manual. 6th edition, revised and amended. -M.: Norm: INFRA-M, 2012. - p. 142-143.

3. International private law: Manual / Responsible editor G.K. Dmitrieva. - M., 2006. - p. 656.

4. Erpileva N.Y. International private law: Manual: - M., 2004. - p. 560 .

5. N.A.Khaustova. Protection of labor rights of citizens in international private law: [Electronic resource]: Dis. ... cand. jurid. science: 12.00.03. - M.: RGB, 2006. - p. 42-45.

6. Ivanov S.A. International Labor Law // Labor Law: Encyclopedic Dictionary. 4th ed. Under editorial of V.S. Andreev, K.P.Gorshenin, M.L.Zakharova and others. M.: Soviet Encyclopedia, 1979, p 217;

7. Kiselev I.Y. Comparative and international labor law. Textbook for high schools. M., 1999, p.p. 447-449;

8. Lushnikova M.V.,Lushnikov A.M. International and comparative labor law and social security law: an introduction to the course. p.60;

9. Potkina M.A. On the structure of the institute of international sports labor law // The second congress of the Permian legal scholars. Proceedings of the international scientific-practical conference (Perm, Perm State National Research University, 28-29 October 2011). Perm, 2011. p. 269;

10. Shuraleva S.V. Legal regulation of individual and collective labor relations in multinational corporations in Russia. Monograph. Ed. L.Y.Bugrov. Perm: Perm. Perm State National Research University Press, 2012. p.68;

11. Thomas C., Oelz M., Beaudonnet X. The use of international labor law in domestic courts: Theory, recent jurisprudence, and practical implications // Les normesinternationales du travail: un patrimoine pour l'avenir Mélanges en l'honneur de Nicolas Valticos. J.-C. Javillier, B. Gernigon (eds.). Geneva: ILO 2004. p. 253, and others works.

12. Ivanov S.A. Problems of international regulation of labor. M.: Science, 1964. p.102.

13. Ivanov S.A. International Labor Law // Labor Law: Encyclopedic Dictionary. p. 217

14. Kharitonov S.A. Workers with family responsibilities: the differentiation of legal regulation as a means of ensuring international labor and Russian labor law equal opportunities. Dissertation for the candidate of law. Sciences. Perm, 2003. 5-6, 9-13.

15. A.H.Saidov International human rights law. M.: GPI RAS, 2002.

16. International humanitarian law. Textbook. Ed. and I. Kapustin. M.: Higher Education Yurayt-2009 p. 72-87.

17. D.B. Levin Actual problems of the theory of international law. M.: Science, 1974. p. 99

18. Bekyashev D.K. International labor law. Tutorial. p. 8.

19. Valticos N. International Labour Law, Deventer, 1977. p. 17.

20. Servais J.-M. International Labour Law. p. 19.

21. Erpyleva N.Y. Individuals as subjects of international labor law and international education law // Law and Politics, №5, 2009. p.p. 1048-1068.

22. Swepston L. International Labour Law //Comparative Labor Law and Industrial Relations in Industrialized Market Economies. R. Blanpain (ed.) Wolters Kluwer, X ed., 2010. p. 141.

23. Chernyaeva D.V. Decree. Op. p. 21.

24. Shesteryakova I.V. International legal regulation of labor. Under editorial of N.P. Antipov. Saratov, 2004, p. 15; she is: the question of the teaching methods of the international labor law // Problems of international and comparative labor law and social security law. Collection of materials of international scientific and practical conference. Omsk: Omsk State University, 2006, p 32.

25. Semeshko A.I. International treaties in the sphere of labor and their inclusion in the labor law in Russia. Abstract of diss. ... Ph.D. Perm, 2009. p.p. 7-8.

26. International private law // H.R. Rahmonqulov and others. T.: The world of economy and law, 2002. - p.448; The problems of private international law. // Ed. N.I.Marysheva. - M.: 2000. - p.218;

27. Boguslavskiy M.M. Private International Law: Textbook. 6th ed., Rev. and add. -M.: Norm: INFRA-M, 2012. - p.704;

28. The problems of international private law and development prospects. Tashkent: "Adabiyot uchqunlari" publishing house, 2014. p.282. (H.A.Rahmankulov, V.Y.Ergashev and others);

29. Peretersky I.S. Krylov Sat. Private International Law. M., 1959. p.19;

30. Luntz L.A. The course of private international law. The 3 volumes. T.I. M., 1973. p. 33;
31. Private International Law: Contemporary Issues. In 2 books. Book $1 /$ Ed. Editor M.M. Bohuslav. M., 1993.;

32. Lebedev S.N. On the nature of private international law // the Soviet Yearbook of International Law, 1978. M., 1980.;

33. N.A.Haustova. Protecting labor rights in private international law: [electronic resource]: Dis. ... Cand. jurid. Sciences: 12.00.03. - M.: RSL, 2006. - p. 42-45.

34. Peretersky I.S. Krylov Sat. Private International Law. Textbook. 1946. - p. 5.

35. Luntz L.A. Course of private international law. The special part. M., 1975. - p. 10.

36. N.A.Haustova. Protecting labor rights in private international law: [electronic resource]: Dis. ... Cand. jurid. Sciences: 12.00.03. - M.: RSL, 2006. - p. 42-45.

37. N.A.Haustova. Protecting labor rights in private international law: [electronic resource]: Dis. ... Cand. jurid. Sciences: 12.00.03. - M. RSL, 2006. - p. 42-45.

38. Zvekov V.P. Private International Law: The course lectures. M., 1999. - p. 410.

39. Private International Law: Textbook / L.P. Anufrieva, K.A. Bekyashev G.K. Dmitrieva, etc.; Ans. Ed. G.K. Dmitrieva. - 2nd ed., Rev. and add - M .: T.C. Welby, Publishing House of the Prospectus, 2004. - p. 547-548

40. Bulletin of the Supreme Council of the Republic of Uzbekistan, 1993, № 1, p. 4.

41. Tolstix V.L. Conflict regulation in international private law. p.206. 